\title{
ON THE ROLE OF THE THEATRICAL AGENT IN OPERATIC CIRCUITS AT THE TURN OF THE TWENTIETH CENTURY THE CASE OF THE EASTERN ADRIATIC COAST
}

\author{
CRISTINA SCUDERI \\ Karl-Franzens-Universität Graz
}

\begin{abstract}
Izvleček: V članku je obravnavana vloga gledališkega agenta $v$ opernih krogih na vzhodni jadranski obali konec 19. in na začetku 20. stoletja $z$ vidika njegovih odnosov z gledališko upravo, gledališkim impresarijem in drugimi agenti. Pri organizaciji opernih sezon so sodelovali najrazličnejši gledališki agenti, katerih način delovanja se je razlikoval.
\end{abstract}

Ključne besede: gledališki agent, impresarij, opera, vzhodna jadranska obala, 19. stoletje, 20. stoletje

\begin{abstract}
The article examines the role of the theatrical agent in the operatic circuits of the late nineteenth and early twentieth centuries on the eastern Adriatic coast in the light of his relations with theatre management, impresarios and fellow agents. There were many different types of theatrical agent involved in managing operatic seasons, and they had different working practices.
\end{abstract}

Keywords: theatrical agent, impresario, opera, eastern Adriatic coast, nineteenth century, twentieth century

For many decades around the turn of the nineteenth and twentieth centuries the theatres of the eastern Adriatic coast witnessed an intense succession of operatic seasons through the work of singers, orchestras and impresarios drawn mainly from the Italian peninsula. ${ }^{1}$ The process of proposing an operatic season usually began with an impresario's letter to a theatre management. The impresario, much like a singer or orchestral musician (although to a lesser extent than those two), could be represented by an agent who managed the business. Theatres such as those of Pula, Rijeka, Zadar, Šibenik and Split enjoyed a long contact with theatrical agents, whose mediation was reflected in a wide and colourful spread of cases, which today add to our knowledge about the phenomenon of operatic organization up to the First World War.

Although the figure and role of the theatrical agent within an Italian context have already been thoroughly discussed in various contributions, stretching from the works of John Rosselli in the 1980s up to the monograph by Livia Cavaglieri (who studied the figure of the agent as a trait d'union between art and market, taking account of the census

For advice regarding this paper, the author wishes to thank Ivano Cavallini, Nicola Montenz, Noemi Silvestri, Vittorio Vella, Michael Walter and the Institut für Musikwissenschaft, Universität Graz.

1 On this topic, see Scuderi, "Organizzare l'opera" and Scuderi's earlier "Management of Opera". 
of agents active in Milan in the nineteenth century), ${ }^{2}$ I can add some unpublished data on the mediation that occurred between theatrical management and impresario along the eastern Adriatic coast, which is something less well known than the classic and more frequent mediation between impresario and singer.

What, then, was the agent's role in contracting with the impresario for the territory in question? How did he try to secure a contract for his client? During my research I came across a plethora of different types of agent and modus operandi, including both the classic case of the agent who merely handled his clients "from above" like pawns on a chessboard and that of the agent who would very concretely take on the role of impresario when necessary and launch proposals for operatic seasons that entailed his personal involvement in their realization. Then there were the "exclusivist" agents (i.e., those who worked completely independently, avoiding cooperation with colleagues) and others who were willing to compromise and collaborate - these would readily combine with other agents, benefiting from the division of profits according to an agreed percentage. The personality of an agent also emerged from the greater or lesser amount of trust placed in the client.

It was not unusual for an agent to jeopardize negotiations with a theatrical management because he had given good opportunities to dishonest clients, or for an agent to deal only with recommended people, being careful not to represent unknowns or young strangers. There were those who represented the same impresario in several locations and those who dealt with several impresarios in the same location, perhaps even during the same season, creating embarrassing incidents. Finally, there was the seemingly selfcontradictory case of agents who had themselves represented as well, thus generating an unbelievable chain of intermediaries: the impresario represented by the agent, who was in turn represented by the agency's own representative.

A look at the hive of relationships that flourished from the 1870 s onwards, when the work of theatrical agencies began to become a more established practice, will help to define more precisely the mechanisms that regulated operatic seasons across the Adriatic.

It has been written that, historically, the first mediation office was founded in Milan in 1870 by Icilio Polese Santarnecchi and Pietro Ravizza. ${ }^{3}$ Actually, through the correspondence from the Istrian-Dalmatian coast, we can see that already the year before, the triad of Amilcare Bellotti, Eugenio Lombardi and Luigi Enrico Tettoni from Milan and Camillo de Clemente from Florence wrote letters giving the address of what was in all respects recognizable as a "theatrical agency". ${ }^{4}$ Ravizza was also in contact with the

2 Rosselli, “Agenti teatrali nel mondo dell'opera”; Cavaglieri, Tra arte e mercato. On the subject of impresarios, conversely, Rosselli's masterpiece L'impresario d'opera retains its validity.

3 This refers to spoken theatre, since agencies for opera already existed. See Azzaroni, Del teatro e dintorni, 117-120; also quoted in Ferrari, Intorno al palcoscenico, 26.

4 The first three had created the Agenzia del Monitore dei Teatri (see letterhead of the theatrical agency Monitore dei Teatri, Milan, 20 March 1869, DS-60, envelope 4, Državni arhiv u Rijeci [HR-DARI-557]), while Camillo de Clemente can be linked to a letterhead in which it is clearly stated: "Theatrical agency $\mid$ At the Newspaper office | L'Arlecchino | in Florence via Cavour, 11". Letterhead of the theatrical agency L'Arlecchino, Florence, November 1869, DS-60, envelope 4, HR-DARI-557. Original in Italian: "Agenzia Teatrale | Presso l'ufficio del Giornale | L'Arlecchino | in Firenze via Cavour, 11". 
theatre managements in both Zadar and Šibenik on several occasions, but this always involved spoken theatre, as already suggested by his letterhead, which also revealed the address of his Agenzia Teatrale Drammatica, located in Via Pantano 4 in Milan, the main organ of which was Il Piccolo Faust, a weekly artistic-theatrical periodical edited by Antonio Fiacchi. ${ }^{5}$ Most of the agencies that are referenced on the coast were based in Milan. On Istrian and Dalmatian territory itself, it is hard to find agencies with their own permanent offices. The "first theatrical agency", that of Lodovico Selles, was documented in Pula only in $1914 .^{6}$

In Zadar it was only after the First World War that Alessandro Meola's agency was founded "for the recruitment of variety artists, drama, music companies and various shows, operettas, comedies etc. etc.", 7 again not dedicated specifically to managing opera, as shown by this formulation.

Agencies dealing with opera performances usually handled the formation of singing and dancing companies; they recruited individual artists, the maestri concertatori and conductors, the chorus instructors - as they were still called. They managed choreographers, rented scores, costumes and equipment, and negotiated the purchase of new scores. Some agents also had singing schools: this was the case with the agent and singer Cesare Castelli, who used to send his own brochure to Dalmatia, advertising, as an adjunct to his agency, "at very low prices, a singing and declamation school staffed by distinguished professors". 8

5 There is evidence for Ravizza's correspondence in Zadar between 1884 and 1894, and in Šibenik in 1885. His letterhead preserved in Dalmatia reads: "Dramatic Theatrical Agency | Pietro Ravizza | of Erminia Magistrelli Azimonti | (Founded in 1868) | Milan 23, Piazza del Duomo, 23 | correspondent | and | representative | of the agency | Il Piccolo Faust | Artistic Literary Periodical | weekly of Bologna" and, with another address: "Dramatic Theatrical Agency $\mid$ of $\mid$ Pietro Ravizza | v. Pantano 4 | Milan Representation in Bologna | Agency of the | Piccolo Faust || Agency's organ | Il Piccolo Faust | Weekly artistic and theatrical magazine | Editor A. Fiacchi - Bologna". Original in Italian: "Agenzia Teatrale Drammatica | Pietro Ravizza | di Erminia Magistrelli Azimonti | (Fondata nel 1868) | Milano 23, Piazza del Duomo, 23 | corrispondente | e | rappresentante | dell'agenzia | Il Piccolo Faust | Periodico Artistico Letterario | settimanale di Bologna"; "Agenzia Teatrale Drammatica | di | Pietro Ravizza | v. Pantano 4 | Milano Rappresentanza in Bologna | Agenzia del | Piccolo Faust || Organo dell'agenzia | Il Piccolo Faust | Periodico artisticoteatrale settimanale | Direzione A. Fiacchi - Bologna”.

6 See Lodovico Selles's letter to the theatre management in Zadar, Pula, 9 April 1914, Kazalište "Verdi" u Zadru 1863-1936, envelope 13, Državni arhiv u Zadru (HR-DAZD-252).

7 "[...] per la scritturazione degli artisti di varietà, compagnie di prosa e musica e spettacoli variati, operette, commedie ecc. ecc." Alessandro Meola to the theatre management in Šibenik, 13 April 1920, Kazalište i kino "Mazzoleni" - Šibenik (1863-1945), envelope 2a, Državni arhiv u Šibeniku (HR-DAŠI-103). His letterhead simply read: "Theatrical Affairs | Alessandro Meola | Zadar". Original in Italian: "Affari Teatrali | Alessandro Meola | Zara”. On the previous presence of impresarios who organized the engagement of Italian musicians in Zadar see: Sabalich, Cronistoria aneddotica; Blažeković, "Glazbeni život Zadra u 19. stoljeću”; Pederin, "Državno sunce".

8 "[...] a limitatissimi prezzi una scuola di canto e declamazione impartita da distintissimi professori". "The Agency under the firm of Cesare Castelli e C.", continued the brochure, "will be open from 9 a.m. to 5 p.m. every day and will be responsible for the formation and contractual 
The letter that the impresario usually addressed to the theatre's management, or sometimes to the theatre's governing body, to offer his services could have therefore also been written by an intermediary operating on the impresario's behalf. In such cases, the name of the impresario was either given in full or omitted. An agent who preferred to omit the name of the impresario would address a generic request, underlining, however, the seriousness of his client: "An honest and hard-working theatrical impresario client of mine entrusted me to serve the municipal theatre of this city on his behalf $[\ldots] " ;$.9 or: "Solicited by a distinguished client of mine, known as a serious and solvent person, who would be willing immediately to submit exceptional proposals for the staging of an opera during the forthcoming autumn season at this theatre, I earnestly invite Your Excellency to provide me with information on the matter". ${ }^{10}$ Or again: "I will make it my business to submit for Your Lordships' approval a splendid project for an operatic spectacle, on behalf of a renowned company, serious and solvent, that can offer every possible guarantee of itself". ${ }^{11}$ The name of the interested party never appeared in these cases: the agency negotiated on his behalf. However, it was important to declare the subject's solvency immediately, even if only presumed. An impresario without solid capital would certainly not have attracted the attention of a theatre management.

engagement of singing and dancing companies, and of choral and orchestral bodies, and will provide to impresarios theatres both municipal and social and private; it will provide, in accordance with the venues, suitable and reliable artists for the good execution of the parts entrusted to them in the shows, and will obtain the greatest economies regarding both artistic personnel and suppliers, and will endeavour to provide impresarios with all the moral and material support they need to start and successfully finish their theatrical ventures". See the brochure Agenzia teatrale Cesare Castelli, Kazalište "Verdi" u Zadru 1863-1936, envelope 7, HR-DAZD-252. Original in Italian: "L'Agenzia sotto la ditta Cesare Castelli e C. sarà aperta dalle ore 9 alle 5 pom. in tutti i giorni e s'incaricherà della formazione e scritturazione di compagnie di canto e ballo, di masse corali ed orchestrali, procurerà agl'Impresari Teatri tanto Municipali che Sociali e privati, fornirà, secondo le piazze, Artisti idonei e sicuri per la buona esecuzione delle parti loro affidate negli spettacoli, procurerà le massime economie tanto nel personale artistico, quanto nei fornitori, e si adopererà onde gli impresari possano avere tutti gli appoggi morali e materiali al fine di iniziare e condurre a buon termine le loro imprese teatrali".

9 "Un mio cliente impresario teatrale, persona onesta e facoltosa mi dà incarico perché io tratti cotesto teatro municipale per suo conto". Thus, for example, Vincenzo Ceruso, who owned a theatrical agency in Milan, wrote to the New Theatre in Split (see Vincenzo Ceruso to the President of the Theatre in Split, Milan, 9 January 1898, Kazalište 1/ kut. I-XII, Muzej Grada Splita [HR-MGS]). Another example is the lawyer Michele Spano who wrote from Milan to Split on behalf of an unspecified client (see Michele Spano to the direction of the theatre in Split, Milan, 24 February 1896, Kazalište 1/ kut. I-XII, HR-MGS).

10 "Sollecitato da un egregio mio cliente, noto quale persona seria e solvibile, che sarebbe disposto a presentare anche immediatamente eccezionali proposte di spettacolo d'opera per la p.v. stagione d'autunno a codesto teatro, interesso vivamente l'esperimentata cortesia della S.V. a volermi favorire informazioni in proposito". Luigi Grabinski Broglio to the theatre management in Zadar, Milan, 29 May 1906, Kazalište "Verdi" u Zadru 1863-1936, envelope 26, HR-DAZD-252.

11 "Mi farò premura di sottoporre all'approvazione della S.V. uno splendido progetto di spettacolo d'opera, per conto di una rinomata ditta, seria e solvibile, la quale può offrire di sé ogni possibile garanzia". Luigi Grabinski Broglio to the theatre management in Šibenik, Milan, 25 January 1901, Kazalište i kino “Mazzoleni” - Šibenik (1863-1945), envelope 1, HR-DAŠI-103. 
As for impresarios, it was also important for agents to demonstrate that they maintained an extensive network of contacts. "We do ourselves the honour of bringing to your attention", as we read in a presentation of the theatrical agency L'Arlecchino, which was offering its services to Rijeka (Fiume), "that our extensive relations in the world of [performing] artists, and our wide connections allow us to hope that in the management of the companies' business we will be able to offer the best possible decisions and the utmost diligence and alertness in protecting their interests". ${ }^{12}$ In the case of Antonio Lana (also known as Don Ciccio - a hybrid case of a Zadar agent/impresario also operating in Milan) these "extensive relations" became something immoderately vast, the following description of which is indicative of his breadth of contacts and long years of activity, as well as revealing a touch of megalomania:

I have very good relations with all artists, from the highest to the lowest; with music publishers; with actors of all kinds; directors of operetta companies; property masters, stage hands, set designers, theatrical shoemakers and costume designers, not only from Italy, but also from abroad, and I can obtain facilities from all of them, because, thanks to God, I have always traded with honesty, and they love me. ${ }^{13}$

It was therefore not enough to know singers, from whom to select good casts: it was also necessary to have a relationship with each of the individual categories that made up the operatic production machine.

One of the best examples of the handling of contacts between theatre management and impresario, probably more sober than Lana's, is provided by the agent Giovanni Simonetti from Trieste, who perhaps had more extensive relations with the theatres on the coast than anyone else. Simonetti was in contact with almost all the towns in Istria and Dalmatia and ran the newspaper L'Arte, together with an adjoining theatrical agency. ${ }^{14}$ In Zadar, he suggested various impresarios to his clients over the years (we have the names of Pietro Cesari, Augusto Romiti, Rinaldo Rosini and Gino Borboni, for example); there, he negotiated on

12 "Ci facciamo un pregio di portare a vostra conoscenza che le nostre estese relazioni nella classe degli artisti, e le nostre vaste aderenze ci permettono sperare che nella gestione degl'interessi delle Imprese potremo offrire i migliori partiti possibili, la massima diligenza ed attività nel tutelarne le convenienze". Letterhead of the theatrical agency L'Arlecchino, signed by Camillo de Clemente for the theatre management in Rijeka, Florence, November 1869, DS-60, envelope 4, HR-DARI-557.

13 "Sono in ottime relazioni con tutti gli artisti dai più grandi ai più piccoli; cogli editori di musica; coi capocomici di tutti i generi; direttori di compagnie d'operette; attrezzisti, macchinisti, scenografi, calzolai teatrali, vestiaristi non solo d'Italia, ma anche dell'Estero e posso avere delle facilitazioni da tutti, perché grazie a Dio ho trattato sempre con onestà e mi vogliono bene". Antonio Lana to Gajo Filomen Bulat, Milan, 18 March 1893, Kazalište 3/ kut. I-XII, HR-MGS.

${ }^{14}$ The only city where we do not find traces of his activity is Pula, from where criticism was directed at his newspaper (as well as in Trieste, L'Arte had offices also in Florence and Milan), which was mercilessly described by its pseudonymous detractor Artù as a "lurid but shabby rag" and an "extortionate rag that lives off what poor singers pay for not being panned and continue to pay in order to be praised". "Nostre corrispondenze", L'Eco di Pola, 19 October 1889. Original in Italian: "lurido sì ma cencioso giornalucolo"; "giornalucolo revolver che vive alle spalle di quello che i poveri cantanti pagano per non venire strigliati e pagano ancora per essere lodati". 
behalf of the impresario Giulio Milani in 1908, in order to obtain an operatic season: "I permit myself to ask", wrote Simonetti, "if you were willing to negotiate with the usual and experienced impresario Giulio Milani, who took on the opera season at this theatre [...] from 5 September to 25 October, for the hire of this city's Teatro Verdi for the usual autumn operatic season, and if so, what the terms would be". ${ }^{15}$ This was a typical opening of a correspondence with a theatre management, where, unlike in the previous examples, the name of the impresario was not withheld, since Milani had evidently already made a good impression. When the client was illustrious, it was indeed in the agent's interest to reveal his identity. Among Simonetti's names was Sonzogno, whose company was promptly offered to Rijeka for performances of Cavalleria Rusticana and Pagliacci in 1893. His mediation services were additionally directed towards drama companies, as was likewise the case with his colleague Enrico Gallina, who later became the representative of all the theatres on the eastern Adriatic seaboard. ${ }^{16}$ Gallina operated in the area only at the start of the twentieth century, while Simonetti's time-span was much longer, going back to 1877. Giuseppe Ullmann also dealt with drama companies, and all three of them owned agencies in Trieste that managed opera, operetta and spoken drama.

Ullmann, who came from a Jewish family, one that included the impresario Rodolfo Ullmann, ${ }^{17}$ director of the philodramatic theatre in Trieste, and his brother Vittorio, secretary to Sarah Bernhardt and Maurizio Strakosch, ${ }^{18}$ as well as director of two theatres in Paris (Théâtre de la Renaissance and Théâtre Sarah Bernhardt), ${ }^{19}$ was in charge of negotiations for theatres in Trieste, Istria, Dalmatia, Friuli and the Venetian provinces. Hence, a rather extensive area. Luciano Revere likewise came from Trieste (his agency was called Revere \& Gallina), ${ }^{20}$ as did the agent Pietro Anselmi, who was also the publisher and editor of the magazine $I l$ Teatro: giornale di lettere, arti e teatri, with offices in Trieste and Venice.

15 "Mi permetto chiedere se fossero propensi trattare col solito ed esperto impresario Giulio Milani che assunse la stagione d'opera a questo teatro [...] dal 5.9 al 25.10, per l'appalto di codesto teatro Verdi per la solita stagione d'opera autunnale e nell'affermativa quali sarebbero le condizioni". Giovanni Simonetti to the theatre direction in Zadar, Zadar, 1908, Kazalište "Verdi" u Zadru 1863-1936, envelope 26, HR-DAZD-252.

${ }^{16}$ See Giovanni Mazzoleni to Riccardo Bovi-Campeggi, Šibenik, 27 November 1910, Kazalište i kino "Mazzoleni" - Šibenik (1863-1945), envelope 2b, HR-DAŠI-103. Enrico Gallina was an actor and brother of the playwright Giacinto Gallina.

${ }^{17}$ On the figure of Rodolfo Ullmann, see Quazzolo, "L'impresariato teatrale".

${ }^{18}$ It is Strakosch himself who reveals that Vittorio Ullmann was also an "impresario in Cairo". Strakosch and Schürmann, L'impresario in angustie, 295.

${ }^{19}$ Zubini, Cittavecchia, 61.

${ }^{20}$ Enrico Gallina later joined forces with Luciano Revere, founding the Revere \& Gallina agency ("Revere \& Gallina | Theatrical Affairs | Trieste | v. Sanità, 4, postal address | Telegrams: Revere - Trieste | Gallina - Trieste"). In the Dalmatian archives one can also find their slightly different letterhead: "Revere \& Gallina | theatrical affairs | agents | exclusively for the theatres in Venezia Giulia". See Enrico Gallina to Carlo Battistelli, Trieste, 26 May 1920, Kazalište "Verdi" u Zadru 1863-1936, envelope 27, HR-DAZD-252. Original in Italian: "Revere \& Gallina|Affari teatrali | Trieste | v. Sanità, 4, i.p | Telegrammi: Revere - Trieste | Gallina - Trieste"; "Revere \& Gallina | affari teatrali | agenti | esclusivi dei teatri della Venezia Giulia”. 
Some agents owned arts-related journals, which acted as organs for the respective theatrical agency. It was often said that "the journal is to the agent what the legal code is to the lawyer"; ${ }^{21}$ the careers of the singers were charted in its columns, where they were presented and advertised, but other content could also be found, such as criticism of "political" newspapers. The articles were sometimes paid for by the singers, depending on the type of piece: the higher the payment, the more important and visible the singer would be. ${ }^{22}$ The clientele of impresarios, on the other hand, was much less visible and was less frequently mentioned. Several agents approached the managements of the coastal theatres also in order to request a subscription to the journal or its renewal. ${ }^{23}$ This was the case with the Curiel theatrical agency with its La Frusta teatrale or Lamperti with his La Rivista teatrale; there were also ones who wrote to managements proposing a subscription to $L a$ Scena illustrata. The agent Sante Utili, based in Milan, ${ }^{24}$ owned the journal Movimento artistico, which was distributed free of charge to theatre managements and published twice a month. This cost-free delivery, and therefore the agent's investment, certainly paid for itself by bringing the agency and the artists engaged via it to wider public notice. The agency owned by Giuseppe Bergamin, who was active in Rijeka, Zadar and Split, controlled the Gazzetta teatrale italiana. Carlo Brosovich, of Dalmatian origin, also had

21 “[...] il giornale è per l'agente quello che è il codice per l'avvocato". "Medaglioni artistici: l'agente teatrale", La musica popolare, 16 July 1883, p. 120. The author of this article did not hold the figure of the theatrical agent at all in high esteem, seeing that he wrote: "The theatrical agent is by origin either a lawyer without clients or a professor of literature without pupils - or maybe even a fellow who, after having amused himself imitating other people's calligraphic hieroglyphics, other people's signatures, founds a theatrical rag together with its linked agency". Original in Italian: "L'agente teatrale è, in origine, o un avvocato senza clienti, o un professore di letteratura senza scolari - o magari anche un tale che, dopo essersi divertito ad imitare gli altrui geroglifici calligrafici, le altrui firme, fonda un giornaluccio teatrale con relativa agenzia".

${ }^{22}$ La Musica popolare described this phenomenon with irony and a touch of malice: "And that's how those newspapers have articles for 20 and 100 francs. Whoever pays the latter sum, I believe, is also entitled to a biography and associated portrait. [...] The agent, of course, gets a set percentage of every contract concluded through him - but this percentage can even exceed the artist's salary. And the artist, hoping to make a career, pays up, perhaps even takes the bread out of his own mouth and keeps quiet. [...] Reader: you ask me whether he at least knows something about singing and music ... No! Absolutely not! It is already something if he knows how to distinguish a bass from a ... soprano [...]". "Medaglioni artistici: l'agente teatrale", La musica popolare, 16 July 1883, p. 120. Original in Italian: "Ed è così che quei giornali hanno gli articoli da 20 e da 100 franchi. Chi paga quest'ultima somma, credo, abbia diritto anche alla biografia e relativo ritratto. [...] L'agente, naturalmente, ha un tanto per cento su ogni contratto concluso per suo mezzo - ma questo tanto può anche superare la paga dell'artista. E questi, sperando far carriera, paga, si toglie magari di bocca il pane e tace. [...] Lettore: tu mi domandi se egli almeno s'intende di canto, di musica... No! Assolutamente no! È già molto se egli sa distinguere un basso da un... soprano [...]".

${ }^{23}$ The management of the Adamich Theatre in Rijeka in the 1870s, for example, subscribed to the Rivista teatrale melodrammatica, edited by Orlando Viviani and Angelo Chinelli (the Asmodeo reports an Angelo Chinelli as being a "supreme tenor, a master in the art of singing and acting", 1888 , p. 24). I do not know whether this is the same person. Original in Italian: "primo tenore assoluto, maestro nell'arte del canto e della scena".

${ }^{24}$ The agency also had branch offices in Rome, Naples, Turin, Florence and Bologna. 
his own journal, Il Trovatore, of which he was the owner-manager. ${ }^{25}$ There were also those who, like Count Luigi Grabinski Broglio, had taken over other theatrical agencies - in his case, the Cambiaggio theatrical agency around 1896 - although in his letters to coastal managements he retained the letterhead of the original agency. ${ }^{26}$

Another case was that of an agent who did not always act on behalf of third parties but proposed himself directly as an impresario, such as Curiel. His agency, aimed at artists of all kinds and, as his letterhead promised, "besorgt die Zusammenstellung von Gesangs-, Vortrags-, Tanz-, Varietè-, und Zirkus-Compagnie", ${ }^{27}$ organized tours both abroad and in Italy (including concert tours) and took charge of procuring orchestral musicians and choral singers for the formation of the so-called artistic "mass" ensembles. It also took on the formation of instrumental ensembles. This agency, as befitted a truly international theatrical office, could communicate in Italian, German and French. ${ }^{28}$ However, Curiel would also present himself personally, without providing any mediation: "I offer to take over the theatre for a while for the sake of a performance of Italian opera", he wrote to Rijeka, "supported by talented artists; given my long experience in theatrical affairs as an agent and impresario, I can ensure the brilliant success of the enterprise". ${ }^{29}$ An agent was here indistinguishable from an impresario; ${ }^{30}$ depending on

${ }^{25}$ Carlo Brosovich, whose agency was based in via Santa Radegonda 11 in Milan and via Monte Napoleone 22, was probably active for a time in Trieste, a city from which some of his letters come. Among the other agents who owned arts-related newspapers, Codecasa (editor of the Nuovo Don Marzio) and Vittore Deliliers (editor of the Rivista Melodrammatica, later Rassegna melodrammatica) also made contact with the theatres on the coast. These journals were designed for a circle of professionals rather than for the general public. The singers subscribed to them and could thereby, through payment, make themselves known to the theatre management in advance of the latter. See Nicolò, Emma Zilli, 17-18.

${ }^{26}$ On Luigi Grabinski Broglio, see Cavaglieri, Tra arte e mercato, 341. Grabinski Broglio, director of Milan's Teatro Manzoni for some years, was the author of I teatri d'Italia e le principali piazze teatrali estere (Milan: Società Teatrale, 1907), and compiled in collaboration with Vambianchi and Adami the single illustrated issue Nel primo centenario di Giuseppe Verdi (Milan, 1913). In 1916 he founded the Silentium Film cinematographic company. His name appears in the list of Freemasons who belonged to the VIII August Lodge from 1886 to 1924. See Manelli, Bonvicini and Sarri, La massoneria a Bologna, 134. Grabinski Broglio took over the Cambiaggio agency, where Carlo and Giorgio (Carlo's son) Cambiaggio worked. The former's career as an impresario was subordinate to that as a singer. See Rosselli, Elenco provvisorio.

27 "[...] looks after the formation of singing, performing, dancing, variety and circus companies".

${ }^{28}$ The letterhead of his theatrical agency is also preserved in 1917, fasc. 2379, Luogotenenza del Litorale (1850-1918), Consiglierato di Luogotenenza b. 3653, Archivio di Stato di Trieste. Fabiana Licciardi devoted an entire paragraph to the figure of Angelo Curiel in her doctoral thesis "Echi nei Theater-Kino-Varieté di un confine in guerra: Trieste 1914-1918". Her dissertation has recently been published: Licciardi, Theater-Kino-Varieté (the section on Curiel occupies pp. 198-204).

29 "Offro di assumere per alcun tempo il teatro per spettacolo d'opera italiana", he wrote to Fiume, "sostenuto da valenti artisti, stante la mia lunga pratica in affari teatrali, quale agente ed impresario posso assicurare la brillante riuscita dell'impresa". Curiel to the theatre management in Rijeka, Rijeka, 27 October 1917, Direzione del Teatro Comunale di Fiume, envelope 562/1, HR-DARI-557.

${ }^{30}$ On the difference between impresario, artistic director and agent, see Franco Ferrari, Intorno al palcoscenico, 19. 
the situation, a person could assume one role or the other. We have a few overt cases of such agents-cum-impresarios, and we need only look at the stamps and letterheads. For instance, the stamp of the impresario and theatrical agent Ettore Bonturini, who worked in Zadar between 1884 and 1892, mentioned both roles: "Ettore Bonturini | impresario | and theatrical agent | Venice", while the letterhead of Josip Karaman from Split similarly stated both titles, " theatrical agent and impresario" - in both Croatian and Italian in his case. ${ }^{31}$ The subsequent appearance of the inscriptions "concessionaire advertising company" and later "Cinema Elektra" (Karaman also became an owner of photographic equipment) shows us how some agents and impresarios certainly had to adapt to the times, changing their functions at a time when opera performances were giving way to new forms of entertainment.

Some impresarios wrote directly on their agent's letterhead and concluded contracts personally: this was the case with Giulio Milani, using the letterhead of Giuseppe Bergamin, the agent who looked after his interests (evidently in parallel with Simonetti). Such an impresario could be supported by several agents for different venues, as in the case of Paolo Massimini, a well-known Jewish impresario who already held contracts at the Teatro La Fenice in Venice ${ }^{32}$ and was offered in Dalmatia both by the agent Marco Curiel of Milan and by Sante Utili; or as in the case of the impresario Giulio Milani and the impresario Eugenio De Monari, who announced to the theatre management in Zadar: "I have three agencies whose services I employ: Agenzia A. Bignardi, Agenzia G. Argenti \& C. and Agenzia Deliliers". ${ }^{33}$ The impresario's decision to use one or the other agency was probably also dictated by a consideration of the agency's operational geographic range and territorial competence.

We also have the complementary case where two agents could offer the same impresario to the same theatre management simultaneously, probably being unaware of each other. The agent Enrico Carozzi ${ }^{34}$ and the agent Giuseppe Bergamin offered the same

31 "Ettore Bonturini | impresario | ed agente teatrale | Venezia"; "agente ed impresario teatrale". Today, in fact, Karaman from Split is remembered mainly as a film director and photographer, one famous for having captured the coronation of Tsar Nicholas I of Montenegro. See Brunetta, Storia del cinema mondiale, 1331.

32 Paolo Massimini (the "little Strakosch", as he was called) worked in Zadar between 1888 and 1891 on a three-year contract that followed his employment at the Teatro La Fenice in Venice. If the agent Sante Utili considered him a "solvent" subject, Antonio Lana did not share his opinion. Writing to the theatre management in Split, he recounted how Massimini had abandoned an opera company in Spain. See Antonio Lana to Gajo Filomen Bulat, Milan, 18 March 1893, Kazalište 3/ kut. I-XII, HR-MGS.

33 "Io tengo tre agenzie della cui opera mi servo: Agenzia A. Bignardi, Agenzia G. Argenti \& C. e Agenzia Deliliers". Eugenio De Monari to the [theatre management in Zadar], Milan, 13 January 1899, Kazalište "Verdi" u Zadru 1863-1936, envelope 6, HR-DAZD-252. De Monari was a "multi-specialized" impresario, so to speak, dedicated not only to the management of opera seasons: his business card read "Eugenio De Monari \& C. | Lyric Theatre - Operetta - Stage Drama - Variety Theatre - Cinematography | Milan". Original in Italian: "Eugenio De Monari \& C. | Lirica - Operette - Prosa - Varietà - Cinematografia | Milano".

${ }^{34}$ Enrico Carozzi was not only a theatrical agent, but also a dealer in music, instruments and costumes. He also edited the newspaper Asmodeo. 
impresario, Giulio Rossi, with the same operas, to the theatre management in Zadar within a day of each other. ${ }^{35}$ In this case, it is possible that it had been the impresario who suggested to the respective agents in which theatre he would like to try to get the contract for the opera season. The agents would have acted autonomously and independently, unaware of each other.

It could also happen that two agents offered the same impresario simultaneously to the same theatre management - but in concert, dividing the percentage: this happened in Šibenik, where the impresario Ernesto Guerra signed the contract with the Mazzoleni Theatre in 1905. It was pointed out that the contract had been "agreed through the cooperation of the agents Enrico Viscardi from Zadar and Enrico Gallina from Trieste, who are entitled to 3 per cent of the income, to be divided between them". ${ }^{36}$ Guerra employed the famous Compagnia Lillipuziana, a children's company, which, thanks to its young performers, attracted a large and curious audience. ${ }^{37}$ Guerra's case is also emblematic of another phenomenon: namely, that of an impresario who, having earlier been represented by a particular agent on the territory, now decided to contract directly with a theatre management, dispensing with the work of the agent he had previously relied on. After 1905, Guerra entered negotiations directly with the theatre management in Zadar, without having beforehand contacted his agent, Enrico Gallina. This naturally occasioned discontent. Enrico Gallina wrote to the theatre management in Zadar:

I am very sorry that you have arranged things directly with Guerra, and [I say] that not out of interest but out of a moral concern. I have done such a lot to gain permission for Guerra to operate in these provinces with his company. I was the one who won him a contract there, creating an excellent agreement for the management. Now, with little delicacy, Guerra casts me aside, and that is not right. Enough! One learns through life, and I will know how to organize my affairs next time. ${ }^{38}$

${ }^{35}$ See Enrico Carozzi to the theatre management in Zadar, Milan, 29 January 1898, Kazalište "Verdi" u Zadru 1863-1936, envelope 6, HR-DAZD-252; and Giuseppe Bergamin to the theatre management in Zadar, Milan, 28 January 1898, Kazalište "Verdi" u Zadru 1863-1936, envelope 6, HR-DAZD-252.

36 “"...] stipulato colla cooperazione degli agenti Viscardi Enrico di Zara ed Enrico Gallina di Trieste ai quali spetta la proprietà del 3\% sull'introito, da dividersi tra di loro". Article 11, contract between the Management of the Mazzoleni Theatre in Šibenik and Ernesto Guerra, Šibenik, 1905, Kazalište i kino "Mazzoleni” - Šibenik (1863-1945), envelope 2b, HR-DAŠI-103.

${ }^{37}$ The Lilliputian Company's brochure referred to "children under 12 years of age" ("ragazzi inferiori ai 12 anni"). See the brochure Compagnia Lillipuziana, [s.d.], Kazalište "Verdi" u Zadru 1863-1936, envelope 11, HR-DAZD-252. Some information on this group of approximately forty members can be found in Paganuzzi and Brugnoli, La musica a Verona, 358; and Festanti, La biblioteca Panizzi, 212.

38 "Spiacemi assai abbiate combinato direttamente con Guerra e ciò non per l'interesse ma per questione morale. Io ho fatto tanto per far accordare il permesso a Guerra di agire in codeste province colla sua compagnia. Fui io che lo scritturai costì facendo fare un ottimo affare alla Direzione. Ora il Guerra con poca delicatezza mi lascia in un canto e ciò non è giusto. Basta! Vivendo s'impara e saprò regolarmi per un'altra volta". Enrico Gallina to the theatre management in Zadar, Trieste, 4 November 1908, Kazalište "Verdi" u Zadru 1863-1936, envelope 26, HR-DAZD-252. 
Enrico Gallina also seemed to be rather susceptible to competition with other agents, since in Šibenik he begged a certain Ugo Fano not to accept offers from other agents in the piazza of Trieste; "and this because I want to have the pleasure of serving this theatre, as always", he wrote, "and then because I organize tours for other very good companies, which I would naturally wish to take there" ${ }^{39}$ He therefore asked Fano, as he had already done with Giovanni Mazzoleni (director of the eponymous theatre), to honour him with his trust and to rely on him because he would do everything possible to satisfy the theatre's management. It would not have been a matter of interest so much as of "self-respect". 40 In 1913, Mazzoleni called Gallina "our theatrical agent", indicating that the agent had managed to maintain relations with the theatre for several years. It was Mazzoleni himself who also appointed him "representative of all the theatres of Istria and Dalmatia". ${ }^{41}$

Gallina had a privileged relationship with all the directors of the theatres of Istria and Dalmatia, as he himself emphasized in his correspondence. He wrote to the theatre management of Split, for example:

If the management wished to put on an opera performance I could also take charge of it, reflecting that since we have the performance at the Politeama [in Trieste] it is much easier for us both to form the company and to ensure the availability of replacements for any eventuality. ${ }^{42}$

For this type of performance, considered to be the most difficult from an organizational standpoint and one demanding the greatest responsibility, a sort of partnership with the theatre management could have been established, such as Gallina regularly formed in Zadar; Gallina would have taken charge of the performance in detail and would have been content with a share of the profits if there were to be any, just to prove "with an initial experiment" the seriousness of his agency. ${ }^{43}$ If the theatre management had agreed to this, Gallina would have personally gone to the site to work out the details.

The theatre managements drew up agreements with both individual impresarios and agents or even with the agents' representatives rather than with the agents themselves. The representative could also work for more than one theatrical agency on the territory, as in

39 “[...] e ciò perché voglio avere il piacere di servire io, come sempre, codesto teatro e poi perché lavoro al giro di altre buonissime compagnie che farei naturalmente passare per costì". Enrico Gallina to Ugo Fano, Trieste, 25 January 1910, Kazalište i kino “Mazzoleni” - Šibenik (1863-1945), envelope 10, HR-DAŠI-103.

40 "[...] di amor proprio". Enrico Gallina to Ugo Fano, Trieste, 25 January 1910, Kazalište i kino "Mazzoleni" - Šibenik (1863-1945), envelope 10, HR-DAŠI-103.

41 "[...] rappresentante di tutti i teatri d'Istria e Dalmazia". Giovanni Mazzoleni to Riccardo BoviCampeggi, Šibenik, 27 November 1910, Kazalište i kino "Mazzoleni” - Šibenik (1863-1945), envelope 2b, HR-DAŠI-103.

42 " [...] potrei pure incaricarmene, facendo riflettere che avendo noi lo spettacolo a questo Politeama [a Trieste] ci riesce molto più facile tanto la formazione della compagnia quanto la sicurezza dei rimpiazzi per ogni eventualità". Enrico Gallina to the theatre management in Split, Trieste, 25 July 1912, Kazalište 4/ kut. I-XVII, HR-MGS.

43 "[...] con un primo esperimento". Enrico Gallina to the theatre management in Split, Trieste, 25 July 1912, Kazalište 4/ kut. I-XVII, HR-MGS. 
the case of Guido Tambornino, who represented the agencies of Ernesto Iviglia, Roberto Zoppolato and Enrico Carozzi in Milan. ${ }^{44}$

Sometimes, it happened that a theatre management, on receiving a letter from an impresario, responded with a suggestion to approach a trusted theatrical agent directly (i.e., one known to the management, and with whom the management was in contact). In that case, the management would very likely decide out of pure convenience to approach only a familiar agent, thereby avoiding the need to deal with several impresarios. When the Milanese impresario Giuseppe Borboni, director of the journal L'Italia lirica with its adjoining theatrical agency, already well known in the operatic world, wrote to the theatre management in Zadar, he was told to make direct contact with the agent Enrico Gallina in Trieste. This was also common practice in some theatres, as Enrico Viscardi testified when writing to the theatre management in Split: "The management has only one obligation, that of notifying the agent of proposals that come directly to them and advising the proposer to enter into negotiations with the exclusive agent". ${ }^{5}$ Famous or obscure, impresarios could therefore be referred to the same authoritative figure.

There was an instance of an agent, in this case Gino Monaldi from Rome, who wrote to Zadar after learning that the contract for the operatic season had been given to the impresario Eugenio De Monari. He wanted Zadar's theatre management to put him in touch with the latter since he would have "important proposals" to make to him, especially as the season was drawing near. ${ }^{46}$ In this way, the agent was also able to gain new business clients by finding them directly through the management. There was perhaps no better place, seeing that the inherent destination of an impresario's interests was the theatre's board of management.

An agent could also propose more than one client at the same time for the same operatic season: if the first client proved not to be particularly responsive in the theatrical correspondence or aroused suspicions about his actions, the agent could immediately propose another client willing to support the contracted operatic season. ${ }^{47}$ The operatic

${ }^{44}$ See Guido Tambornino to the theatre management in Zadar, Trieste, 29 December 1891, Kazalište "Verdi" u Zadru 1863-1936, envelope 7, HR-DAZD-252.

45 "Alle direzioni non incombe che un obbligo, quello di notiziare l'agente delle proposte che le provenissero direttamente, avvertendo il proponente di rivolgersi per le trattative all'agente esclusivo". Enrico Viscardi to the theatre management in Split, Zadar, 4 November 1895, Kazalište 3/ kut. I-XII, HR-MGS. "When informing the agent," Viscardi continues, "the management mentions whether it would like the proposed performance and gives the necessary instructions. This must be done, however, in such a way as not to disrupt any negotiations that the agent was carrying out beforehand in the interest of all venues". Ibid. Original in Italian: "Nel notiziare l'agente la direzione gli accenna se desidera lo spettacolo che si propone dando le debite istruzioni. Questo deve avvenire però, allo scopo di non intralciare quelle trattative che preventivamente l'agente stesse facendo nell'interesse di tutte le piazze".

46 "[...] importanti proposte". See Gino Monaldi to the theatre management in Zadar, Rome, 18 October 1899, Kazalište "Verdi" u Zadru 1863-1936, envelope 10, HR-DAZD-252.

${ }^{47}$ Grabinski Broglio behaved in this way towards the theatre management in Zadar. He wrote to the management: "I have received your postcard of 30 [May], which came to me unexpectedly and which I am sincerely sorry about, since I thought it was a certainty that Signor Romiti was failing to reply to my letters because he was in direct communication with Your Excellency. While 
project could remain the same, or it could be modified. This action was likely to remain unknown to the agent's clients, who would have not appreciated being in competition with other clients of their own agent.

We also find cases of simultaneous negotiations between the agent-director and the represented impresario-director, i.e., of simultaneous correspondence in the two channels. In this case, the agent's role was minor if the impresario had direct contact with the management. The agent usually retained a percentage of four or five per cent of the earnings ${ }^{48}$ (this could go down to three per cent for just signing the contract with the impresario). ${ }^{49}$ Consequently, the higher the client's income, the higher the agent's recompense would be.

For the agent, not knowing his client thoroughly could constitute a risk. If the latter failed to fulfil his obligations but had previously been presented in a good light, the agent would lose credibility. This is what happened to Sante Utili with the impresario Francesco Razzani, who was presented together with his business partner Delfino Marchelli as a perfect gentleman to the Teatro Nuovo in Zadar. Although Utili was initially convinced that the two would "serve their purpose, honouring me and Your Lordship", he changed his mind within a month, declaring to the management that he regretted not having got to know the impresario well ("a real scoundrel", "a sad subject") and distancing himself

I must therefore disapprove of Signor Romiti's behaviour, which certainly does not correspond to your kind preference and my concern, I hasten to inform you that I have another client prepared to compete, and who had actually accepted precisely at the moment when Romiti's agreement had just been received. This would be Mr. Giulio Milani, a name that I submit to Your Excellency for approval, being delighted to resume negotiations on your behalf". Luigi Grabinski Broglio to the theatre management in Zadar, Milan, 1 June 1903, Kazalište "Verdi" u Zadru 1863-1936, envelope 11, HR-DAZD-252. Original in Italian: "Ricevo la sua cartolina del 30 p.p. che mi giunge inaspettata e sinceramente mi produce immenso dispiacere, poiché ritenevo come cosa certa che il Signor Romiti trascurasse di rispondere alle mie lettere perché in diretta comunicazione colla S.V. Mentre dunque devo riprovare il contegno del Signor Romiti, non rispondente certo alla Sua deferente preferenza ed alla mia premura, mi affretto ad informarla che ho pronto altro cliente che concorrerebbe e che aveva accettato quando appunto era appena intravenuta l'accettazione del Romiti. Questi sarebbe il signor Giulio Milani, nome che sottopongo alla S.V. perché voglia darmi benestare, lietissimo di riprendere le trattative per suo conto".

${ }^{48}$ The percentage did not change for operetta performances, either. "The Presidency", as it was described in the contract between the management of the theatre in Zadar and Antonio Scalvini, director of the eponymous operetta and drama company "remains authorised to withhold from the amounts paid to Dr. Scalvini a commission of 4 per cent for the benefit of the Agency of the journal l'Arte represented by Mr. Giovanni Simonetti" (contract between the presidency of the theatre in Zadar and Antonio Scalvini, Zadar, [1877], Kazalište "Verdi" u Zadru 1863-1936, envelope 4, HR-DAZD-252). According to Ermanno Salucci, at least in 1858 the going percentage was five per cent for Italy and six per cent for abroad. See Salucci, Manuale della giurisrudenza dei teatri, 43. Original in Italian: "La Presidenza resta autorizzata di trattenere sugli importi esborsati al dr. Scalvini la provvigione del 4 per cento a beneficio dell'Agenzia del giornale l'Arte rappresentata dal signor Giovanni Simonetti".

49 See the brochure Agenzia Musicale e Teatrale Luigi Bernini, Zadar, 1891, Kazalište "Verdi" u Zadru 1863-1936, envelope 7, HR-DAZD-252. The commission for contracts regarding operetta, plays, ballet, vaudeville and equestrian companies also amounted to three per cent, to be calculated on the net revenue from the receipts. 
from him. The problem seems to have been linked to debts owed by Razzani for the hiring of the "mass" ensembles. ${ }^{50} \mathrm{He}$ declined any responsibility for the behaviour of his client (who once had been an "honourable client"), stating that there was initially no reason to doubt Razzani's honesty. Other agents, such as Paolo Rocca, preferred not to take any risks, and always presented impresarios whose work had been known for a long time: "You know from experience how I conduct business", Rocca wrote to the theatre management in Zadar, "and that if I did not have a thorough knowledge of the person, I would not dare to act as a guarantor for him". ${ }^{51}$

By cross-checking correspondence in the archives, a preliminary reconstruction of the clients of the main agents operating in the eastern Adriatic was carried out. It was not always possible to retrieve the name of the client, since this was not mentioned in the negotiations. It appears that the clients were mainly from the Teatro Nuovo (later Verdi) in Zadar, which suggests that it was this theatre management that had the most contacts with agents on the peninsula. The predominance of a centre such as Milan is unequivocal (almost all agents corresponded from this city), with Trieste following. However, only those agents dealing with opera (seria, buffa or both) were included. The total number of clients of individual agents in the territory was in fact much larger. It would therefore be interesting and significant to be able to reconstruct in full the dense network of relationships that individual agents cultivated with the coastal theatres, also for types of performances "other" than opera, in order to have a more complete picture that would allow us to map, and consequently assess, the solidity of the existing networks.

50 “[...] servito a dovere, facendo onore a me ed alle S.L.L.Ill.me." Agent Utili hastened to distance himself from him: "For my part, I did not fail to act in all conscience and good faith, as it is my approach to walk under the banner of honesty and loyalty, but unfortunately I was disappointed at this first meeting. I was wrong to place too much trust in him [Razzani], and I spent too many good words on him. [...] I have a superabundance of good references, if needed, to present to the Honourable Presidency, in case Mr. Razzani etc. etc. should wish to blacken my name in front of Your Lordships after his shameful conduct towards my old theatrical home". Sante Utili to the theatre management in Zadar, Zadar, 18 April 1883, Kazalište "Verdi" u Zadru 1863-1936, envelope 5, HR-DAZD-252. Original in Italian: "Dal canto mio non mancai di agire con tutta coscienza e buona fede, essendo mio sistema di camminare sotto la bandiera dell'onestà e lealtà ma purtroppo fui deluso in questo primo incontro. Ebbi torto di prestar troppa fiducia al medesimo [Razzani], e per lui spesi anche troppo buone parole. [...] Ho troppe buone referenze, se occorrono, da presentare a codesta Onorevole Presidenza, se il sig.r Razzani ecc. ecc. volesse farmi nero di fronte alle Signorie Loro, dopo al suo vergognoso modo di agire verso alla mia vecchia casa teatrale".

51 "Ella sa per esperienza come io tratti e che se non conoscessi a fondo la persona non mi azzarderei di farmi mallevadore per lui". Paolo Rocca to Giorgio de Nakic d'Osliak, Milan, 16 June 1893, Kazalište "Verdi" u Zadru 1863-1936, envelope 7, HR-DAZD-252. 


\section{Bibliography}

Azzaroni, Giovanni. Del teatro e dintorni: una storia della legislazione e delle strutture teatrali in Italia nell'Ottocento. Rome: Bulzoni, 1981.

Blažeković, Zdravko. "Glazbeni život Zadra u 19. stoljeću”. In Glazba osjenjena politikom: studije o hrvatskoj glazbi između 17. i 19. stoljeća, edited by Jelena Hekman, 84-101. Zagreb: Matica hrvatska, 2002.

Brunetta, Gian Piero. Storia del cinema mondiale. Torino: Einaudi, 2003.

Cavaglieri, Livia. Tra arte e mercato: agenti e agenzie teatrali nel XIX secolo. Rome: Bulzoni, 2006.

Ferrari, Franco. Intorno al palcoscenico: storie e cronache dell'organizzatore teatrale. Milan: Franco Angeli, 2012.

Festanti, Maurizio, ed. La Biblioteca Panizzi di Reggio Emilia. Reggio Emilia: Comune di Reggio Emilia, Cassa di risparmio di Reggio Emilia, 1997.

Licciardi, Fabiana. Theater-Kino-Varieté nella Prima guerra mondiale: l'industria dell 'intrattenimento in una città al fronte; Trieste 1914-1918. Trieste: EUT, Edizioni Università di Trieste, 2019.

Manelli, Carlo, Eugenio Bonvicini, and Sergio Sarri. La massoneria a Bologna dal XVIII al XX secolo. Tricase: Youcanprint, 2014. https://www.youcanprint.it.

Nicolò, Cecilia. Emma Zilli: una carriera di fine Ottocento. Rome: NeoClassica, 2019.

Paganuzzi, Enrico, and Pierpaolo Brugnoli. La musica a Verona. Verona: Banca mutua popolare, 1976.

Pederin, Ivan. "Državno sunce nad kazalištem i zabavnim životom u Dalmaciji (1825-1865)". Dubrovnik 9, no. 1 (1998): 405-432.

Quazzolo, Paolo. "L'impresariato teatrale: Rodolofo Ullmann e il Teatro filodrammatico". In Shalom Trieste: gli itinerari dell'ebraismo, edited by Adriano Dugulin, 235-242. Trieste: Comune di Trieste, 1998.

Rosselli, John. "Agenti teatrali nel mondo dell'opera lirica italiana dell'Ottocento". Rivista Italiana di Musicologia 17, no. 1 (1982): 134-154.

—. Elenco provvisorio degli impresari e agenti teatrali italiani dal 1770 al 1890. Bologna: Università di Bologna, Dipartimento delle Arti, 1982.

_. L'impresario d'opera: arte e affari nel teatro musicale italiano dell'Ottocento. Turin: EDT, 1985.

Sabalich, Giuseppe. Cronistoria aneddotica del Nobile teatro di Zara: 1781-1881. Zadar: Nani, 1922.

Salucci, Ermanno. Manuale della giurisprudenza dei teatri: con appendice sulla proprietà letteraria teatrale. Florence: Barbèra, Bianchi, 1858.

Scuderi, Cristina. "The Management of Opera in Istria and Dalmatia (1861-1918): A First Survey". Arti Musices 49, no. 2 (2018): 251-267. https://doi.org/10.21857.

_. "Organizzare l'opera tra Pola e Dubrovnik: impresari e loro attività dall'Ausgleich al primo conflitto mondiale”. Rivista Italiana di Musicologia 54 (2019): 5-18.

Strakosch, Moritz, and Joseph Schürmann. L'impresario in angustie: Adelina Patti e altre stelle fuori della leggenda (1886-1893). Milan: Bompiani, 1940.

Zubini, Fabio. Cittavecchia. Trieste: Italo Svevo, 2006. 


\title{
VLOGA GLEDALIŠKEGA AGENTA V OPERNIH KROGIH NA PRELOMU V 20. STOLETJE: PRIMER VZHODNE JADRANSKE OBALE
}

\author{
Povzetek
}

Na vzhodni jadranski obali so od druge polovice 19. stoletja pri organizaciji opernih sezon sodelovali najrazličnejši gledališki agenti. Gledališča v Pulju, na Reki, v Zadru, Šibeniku in Splitu so bila denimo že od nekdaj v stiku z njimi. Njihovo posredništvo se je izražalo v najrazličnejših oblikah, ki bogatijo današnje poznavanje organizacije opernih predstav do prve svetovne vojne. Med njimi so bili tako »klasični« agenti, ki so svoje stranke obravnavali zviška in z njimi delali kot s figurami na šahovnici, kot tudi agenti, ki so po potrebi dejavno prevzeli vlogo impresarija in predstavili predloge za operne sezone, v izvedbo katerih so bili tudi osebno vključeni. Obstajali so tudi »izključujoči« agenti, ki so delovali popolnoma samostojno in se izogibali sodelovanju s kolegi, ter taki, ki so bili pripravljeni sklepati kompromise, sodelovati in združiti moči z drugimi agenti, s katerimi so si na koncu razdelili dobiček na podlagi dogovorjenega deleža.

Agentova osebnost se je odražala tudi v stopnji zaupanja svojim strankam. Neredko je kak agent ogrozil pogajanja z gledališko upravo, ker je ponudil dobro priložnost nepoštenim strankam, spet drugi pa so sklepali pogodbe samo s posamezniki z dobrimi priporočili in pazili, da niso zastopali neznanih ali mladih strank. Bili so tudi taki, ki so zastopali istega impresarija na različnih trgih, in taki, ki so sodelovali z različnimi impresariji na istem trgu ali celo v isti sezoni, s čimer so povzročali neprijetne diplomatske incidente. Poznani so bili tudi protislovni primeri agentov, ki so imeli tudi sami svojega zastopnika, s čimer so ustvarjali neverjetno posredniško verigo: impresarija je zastopal agent, tega pa je zastopal drug predstavnik agencije. Pri vodenju odnosov z jadransko obalo je bila jasna prevladujoča vloga središč, zlasti Milana (skoraj vsi agenti so vodili korespondenco iz tega mesta) in za njim Trsta. 